\title{
PENGEMBANGAN MODUL BERBASIS POE (PREDICT, OBSERVE, EXPLAIN) MATERI USAHA DAN ENERGI DITINJAU DARI KEMAMPUAN KOGNITIF
}

\author{
Aria Tanti Wika Sari ${ }^{1}$ \\ Dedy Hidayatullah Alarifin ${ }^{2}$ \\ Pendidikan Fisika, FKIP, Universitas Muhammadiyah Metro \\ Email: ariatantiwikasari@yahoo.co.id
}

\begin{abstract}
Abstrak
Pelajaran fisika mempersiapkan siswa agar sanggup menghadapi perubahan di dalam kehidupan. Hal ini sebaiknya siswa diberikan sebuah modul yang menarik agar siswa dapat belajar secara mandiri di rumah. Salah satu model pembelajaran yang berpotensi melatihkan siswa untuk memecahkan permasalahan adalah POE. Penelitian ini merupakan penelitian $R \& D$ dengan model prosedural yaitu "model 4D. Model ini terdiri dari 4 tahap pengembangan, yaitu define, design, development dan dissemination. Hasil penelitian ini adalah kualitas modul fisika berbasis POE menurut ahli materi, ahli media, dan ahli bahasa memiliki kriteria kelayakan sangat layak dengan persentase keidealan masing-masing sebesar $80,20 \%, 80,30 \%$, dan $81,25 \%$ dan keefektivitasan modul berbasis POE ditinjau dari kemampuan kognitif siswa mendapat kriteria tinggi.
\end{abstract}

Kata Kunci : Pengembangan, Modul, POE, Kemampuan Kognitif.

\begin{abstract}
Physics to prepare the student to be able to encounter of changes in life. Because it, the student must have an interesting module for students to learn independently at home. One of the model learning is potential of students to solve problems practice is POE. This research is a $R \& D$ with the procedural model that "4-D models. This model consists of four stages of development, there are define, design, development and dissemination. The results of this research is the quality of the modules physics-based POE according to subject matter experts, media specialists, and linguists have eligibility criteria are very decent with their respective ideals percentage of $80,20 \%, 80,30 \%$, and 81,25\%, and the effectiveness of the module-based POE (Predict, Observe, Explain) in terms of the cognitive abilities of the students got high criterion with an overall .
\end{abstract}

Keywords: Development, module, POE, cognitive ability 
Aria Tanti. W. S., Dedy. H. A.- Pengembangan Modul Berbasis ...

\section{PENDAHULUAN}

Sains merupakan salah satu ilmu pengetahuan yang sangat luas, yang terdiri atas kumpulan konsep, prinsip, hukum dan teori yang terbentuk melalui kreativitas, sikap ilmiah dan ketrampilan proses sains. Fisika merupakan ilmu yang mempelajari tentang sifat, hukum-hukum alam, dan aplikasinya dalam kehidupan sehari-hari. Sifat konsep fisika ada yang abstrak, ada juga yang konkret. Konsep fisika yang bersifat abstrak sulit untuk divisualisasikan, sehingga membuat siswa kesulitan dalam menelaah dan memahaminya. Hal inilah yang membuat siswa beranggapan fisika sulit dan tidak menarik.

Kondisi di lapangan saat ini, masih jarang ditemukan media yang dapat memfasilitasi siswa untuk dapat memahami konsep-konsep fisika yang abstrak. Berdasarkan hasil prasurvei tanggal 30 April 2015 dibeberapa SMA dan MA seperti SMA Negeri 5 Metro, SMA Muhammadiyah 1 Metro, MAN 1 Metro tentang modul fisika, diperoleh informasi sebagai berikut:
1. Belum adanya modul fisika yang menarik dan dimengerti oleh siswa.

2. Belum ada modul dengan berbasis POE yang dikembangkan di sekolah - sekolah tersebut.

3. Guru lebih sering menggunakan handout dari pada buku pegangan siswa.

4. Tidak adanya waktu bagi guru untuk mengembangkan modul agar pembelajaran lebih menarik.

Hasil observasi dan wawancara yang dilakukan dengan guru bidang studi fisika dari beberapa sekolah SMA dan MA (SMA Negeri 5 Metro, SMA Muhammadiyah 1 Metro dan MAN 1 Metro) diketahui bahwa nilai UAS tersebut belum terdapat siswa yang tuntas. Hal tersebut ditunjukkan dari hasil observasi dan wawancara terkait dengan siswa yang tidak tuntas ditemukan beberapa permasalahan antara lain: siswa menganggap pelajaran fisika sebagai pelajaran yang sulit dan rumit karena banyak konsep-konsep, masih banyak siswa yang tidak memperhatikan guru ketika sedang menjelaskan materi pelajaran seperti bermain-main dan mengobrol, ketika diberi kesempatan untuk bertanya siswa hanya diam, 
Aria Tanti. W. S., Dedy. H. A.- Pengembangan Modul Berbasis ...

sementara siswa belum memahami materi yang disampaikan guru, masih banyak siswa yang tidak mengerjakan latihan yang diberikan guru secara mandiri, siswa lebih banyak menyalin jawaban yang telah dikerjakan oleh teman atau guru di depan kelas. Siswa tidak bisa belajar mandiri karena siswa tidak mempunyai buku pegangan siswa yang menarik. Siswa tidak mau mencari referensi sendiri atau mencari bahan belajar sendiri. Siswa hanya mengandalkan handout dari guru yang hanya terbatas dengan materi yang akan dipelajari saja. Kemampuan kognitif siswa juga belum terlihat karena masih banyak siswa yang belum tuntas. Sebaiknya siswa tidak hanya diberi handout saja sebab handout hanya berisi materi yang singkat. Hal ini sebaiknya siswa diberikan sebuah modul yang menarik agar siswa dapat belajar secara mandiri di rumah. Modul tersebut dapat berisi uraian yang mudah dimengerti oleh siswa dan modul tersebut dapat berisi sebuah eksperimen sederhana yang membuat siswa ingin mencoba sebuah eksperimen sederhana dirumah. Modul ini berbeda dengan buku pegangan siswa karena dapat membantu siswa belajar secara mandiri di rumah. Modul ini dibuat dengan sistematis dengan bahasa yang mudah dipahami siswa, agar siswa dapat belajar secara mandiri di rumah tanpa bantuan fasilitator atau guru. Menurut Asyhar (2011:155) menyatakan bahwa "Modul adalah salah satu bentuk bahan ajar berbasis cetakan yang dirancang untuk belajar secara mandiri oleh siswa karena itu modul dilengkapi dengan petunjuk untuk belajar sendiri. Dalam hal ini, siswa dapat melakukan kegiatan belajar sendiri tanpa kehadiran guru secara langsung. Modul yang dikembangkan harus mampu meningkatkan motivasi siswa dan efektif dalam mencapai kompetensi yang diharapkan sesuai dengan tingkat kompleksitasnya". Bahan ajar yang hanya berupa modul belum merancang siswa untuk berpikir tingkat tinggi dalam memecahkan permasalahan autentik dalam kehidupan sehari-hari serta mengaitkannya dengan masyarakat dan lingkungan. Salah satu model pembelajaran yang berpotensi melatihkan siswa untuk memecahkan 
Aria Tanti. W. S., Dedy. H. A.- Pengembangan Modul Berbasis ...

permasalahan adalah POE (Predict,

Observe, Explain). Model pembelajaran POE (Predict, Observe, explain) adalah salah satu alternatif yang dapat digunakan oleh para guru untuk menciptakan suasana belajar yang menyenangkan dan berkualitas. Hal ini sesuai dengan hasil penelitiannya Restami (2013) yang menunjukkan bahwa "model pembelajaran POE dapat meningkatkan pehamaman konsep fisika siswa dibandingkan dengan model pembelajaran konvensional". Model pembelajaran POE (predictobserve-explain) adalah salah satu alternatif yang dapat digunakan oleh para guru untuk menciptakan suasana belajar yang menyenangkan dan berkualitas. Menurut Ozdemir (dalam widyaningrum, 2013) mengemukakan bahwa "dalam POE dapat meningkatkan pemahaman konsep sains siswa". Hal ini juga didukung oleh hasil penelitian Rahayu (2013) yang menyatakan bahwa "model pembelajaran POE mampu meningkatkan ketuntasan hasil belajar siswa secara individual" (dalam Yulianto, 2014).
Bahan ajar yang menarik dapat berupa modul yang dibuat menarik supaya siswa ingin membacanya dan tidak bosan untuk mempelajarinya. Bahan ajar ini berupa modul yang berbasis POE yang berguna untuk siswa berfikir secara sains. Modul berbasis POE ini akan berisi uraian yang menarik sehingga siswa tidak bosan untuk membacanya yang mengakibatkan kemampuan kognitif siswa menjadi bertambah. Modul berbasis POE terdapat uraian-uraian tentang percobaan sederhana yang bisa dilakukan siswa secara mandiri. Siswa tidak perlu melakukan percobaan di laboratorium di sekolah, siswa dapat melakukan praktikum secara mandiri dan sederhana di rumah.

Berdasarkan uraian di atas, maka tujuan penelitian pengembangan ini adalah untuk mengembangkan modul fisika berbasis POE (Predict, Observe, Explain) yang layak untuk siswa SMA/MA, untuk mengetahui bagaimana tingkat kelayakan modul fisika yang dikembangkan dengan berbasis POE (Predict, Observe, Explain) menurut penilaian dari ahli materi, ahli media, ahli bahasa dan 
Aria Tanti. W. S., Dedy. H. A.- Pengembangan Modul Berbasis ...

untuk mengetahui keefektivitasan instrumen, yaitu lembar validasi modul berbasis POE (Predict, modul fisika dan observasi. Lembar Observe, explain) ditinjau dari validasi modul fisika, merupakan Kemampuan kognitif siswa.

\section{METODE}

Penelitian ini merupakan penelitian pengembangan (Research and Development). Model penelitian pengembangan yang digunakan adalah model pengembangan prosedural. Model pengembangan prosedural ini secara deskriptif menggambarkan alur atau langkahlangkah prosedural yang harus diikuti untuk menghasilkan suatu produk tertentu, dalam penelitian ini produk yang akan dihasilkan adalah modul fisika berbasis POE. Model pengembangan prosedural biasanya berupa urutan langkah-langkah yang diikuti secara bertahap dari langkah awal hingga langkah akhir. Model pengembangan yang dikembangkan Thiagarajan (dalam Mulyatiningsih, 2014) yaitu "model 4-D. Model ini terdiri dari 4 tahap pengembangan, yaitu define, design, development dan dissemination. Instrumen yang digunakan dalam mengumpulkan data penelitian ini terdiri dari dua jenis instrumen yang digunakan pada tahap pengujian produk oleh beberapa ahli. Sedangkan lembar observasi adalah instrumen untuk meninjau keefektivitasan penggunaan modul fisika berbasis POE pada materi usaha dan energi yang ditinjau dari kemampuan kognitif siswa. Analisis yang dilakukan pada penelitian ini yaitu dengan cara mengelompokan jenis-jenis data yang diperoleh sehingga peneliti mudah memahami data dan menarik kesimpulan.

\section{HASIL DAN PEMBAHASAN}

Modul fisika berbasis POE (Predict, Observe, explain) hasil pengembangan ini telah melewati tahap validasi ahli yaitu ahli materi, ahli media,dan ahli bahasa untuk mendapatkan kelayakan dari modul fisika yang dikembangkan sebelum di uji cobakan dan selanjutnya uji coba produk yaitu meninjau keefektivitasan penggunaan modul, hal ini untuk mengetahui seberapa besar efektivan penggunaan modul ditinjau dari kemampuan kognitif 
Aria Tanti. W. S., Dedy. H. A.- Pengembangan Modul Berbasis ...

siswa di lapangan dengan modul rekapitulasi skor dari hasil validasi fisika yang telah dikembangkan. ahli dan hasil uji coba produk.

Setelah dilakukan semua hal tersebut, maka revisi produk dapat dilakukan.

Tabel 1 hingga tabel 3 merupakan

Tabel 1. Skor validasi modul fisika berbasis POE ahli materi

\begin{tabular}{clcc}
\hline NO & \multicolumn{1}{c}{ SUB KOMPONEN } & $\begin{array}{c}\text { Presentase dari } \\
\text { skor ideal }\end{array}$ & Kriteria \\
\hline 1 & Cakupan Materi & $66,67 \%$ & Layak \\
2 & Keakuratan Materi & $7,5 \%$ & Layak \\
3 & Relevansi & $87,5 \%$ & Sangat Layak \\
4 & Kelengkapan Sajian & $75 \%$ & Layak \\
5 & Penyajian Informasi & $84,38 \%$ & Sangat Layak \\
6 & Penyajian Pembelajaran & $85 \%$ & Sangat Layak \\
7 & Kemutakhiran Materi & $62,50 \%$ & Layak \\
\hline Jumlah skor untuk validasi ahli materi & $80,20 \%$ & Sangat layak \\
\hline
\end{tabular}

Tabel 2. Skor validasi modul fisika berbasis POE ahli media

\begin{tabular}{clcc}
\hline No & SUB KOMPONEN & $\begin{array}{c}\text { Presentase dari } \\
\text { skor Ideal }\end{array}$ & Kriteria \\
\hline 1 & Ukuran fisik modul & $87,50 \%$ & Sangat Layak \\
2 & Tata kulit modul & $78,12 \%$ & Layak \\
3 & Tipografi kulit modul & $81,25 \%$ & Sangat Layak \\
4 & Ilustrasi kulit modul & $81,25 \%$ & Sangat Layak \\
5 & Tata letak isi modul & $79,16 \%$ & Layak \\
6 & Tipografi isi modul & $84,37 \%$ & Sangat Layak \\
7 & Ilustrasi isi modul & $71,87 \%$ & Layak \\
\hline Jumlah skor untuk validasi ahli media & $80,30 \%$ & Sangat Layak \\
\hline
\end{tabular}

Tabel 3. Skor validasi modul fisika berbasis POE ahli bahasa

\begin{tabular}{clcc}
\hline No & \multicolumn{1}{c}{ SUB KOMPONEN } & $\begin{array}{c}\text { Persentase dari } \\
\text { Skor Ideal }\end{array}$ & Kriteria \\
\hline 1 & Komunikatif & $75 \%$ & Layak \\
2 & Dialogis dan Interaktif & $93,75 \%$ & Sangat Layak \\
3 & Kesesuaian dengan Kaidah & $62,5 \%$ & Layak \\
\hline Jumlah Skor untuk validasi ahli bahasa & $81,25 \%$ & Sangat Layak \\
\hline
\end{tabular}


Aria Tanti. W. S., Dedy. H. A.- Pengembangan Modul Berbasis ...

Berdasarkan hasil pengujian dari beberapa ahli terhadap materi, media dan bahasa diperoleh rata-rata persentase seluruh ahli mencapai $80,80 \%$ atau terletak pada kriteria "sangat layak". Hal ini berarti modul berbasis POE dalam ahli materi, ahli media dan ahli bahasa pada materi usaha dan energi telah dinyatakan sangat layak. Berdasarkan data-data tiap ahli di atas, hasil uji kelayakan bahan ajar oleh ahli dapat disajikan dalam bentuk grafik sperti pada gambar 1 di bawah ini.

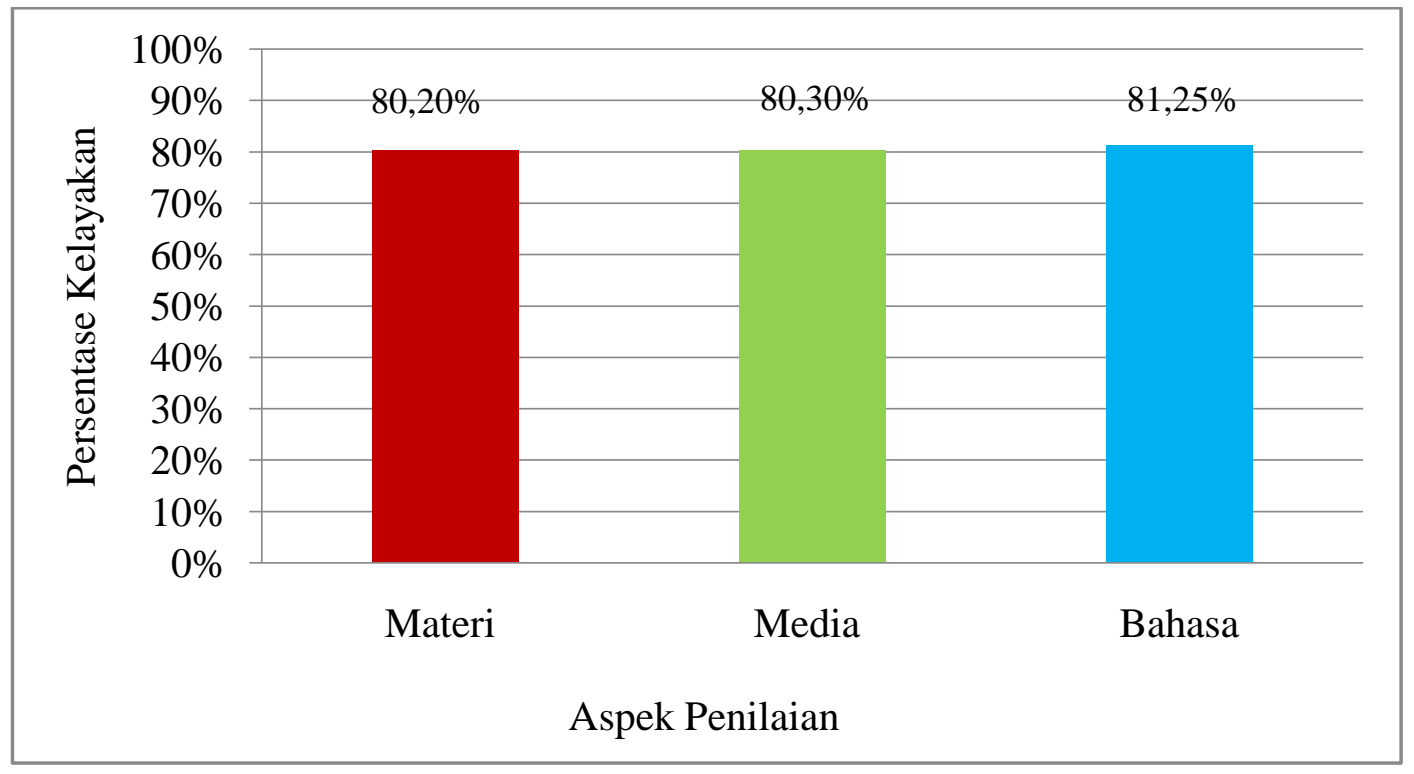

Gambar 1. Grafik hasil validasi dari beberapa ahli terhadap modul fisika berbasis POE (Predict, Observe, explain)

Grafik pada gambar 1 persentase tingkat kelayakan bahan menunjukkan bahwa aspek-aspek ajar adalah sebagai berikut: bahan ajar telah terpenuhi dengan kriteria sangat layak. Aspek materi memiliki presentase sebesar $80,20 \%$. Aspek media memiliki presentase sebesar 87,50\%. Dan aspek bahasa memiliki presentase sebesar $81,25 \%$. Dari data tersebut, maka didapat

$$
\frac{80,20 \%+80,30 \%+81,25 \%}{3}=80,58 \%
$$

Sesuai dengan tabel range persentasi dan kriteria kualitatif bahan ajar, persentase $80,58 \%$ termasuk pada kriteria sangat layak. Dengan demikian dapat disimpulkan, bahwa ditinjau dari aspek materi, aspek 
media, dan aspek bahasa bahan ajar berbasis POE pada materi usaha dan energi yang telah dikembangkan layak untuk dijadikan bahan ajar fisika pada materi usaha dan energi untuk SMA kelas XI(sebelas).
Skor kefektivitasan penggunaan modul ditinjau dari kemampuan kognitif siswa dapat dilihat pada tabel 4 yang tersaji dibawah ini:

Tabel 4. Skor kefektivitasan penggunaan modul ditinjau dari kemampuan kognitif siswa

\begin{tabular}{clccc}
\hline No. & Interval Penilaian & Kriteria & Jumlah Siswa & Persentase \\
\hline 1 & $13 \leq$ Nilai $\leq 16$ & Tinggi & 19 & $76 \%$ \\
2 & $9 \leq$ Nilai $\leq 12$ & Sedang & 6 & $24 \%$ \\
3 & $4 \leq$ Nilai $\leq 8$ & Rendah & 0 & 0 \\
\hline \multicolumn{2}{r}{ Jumlah } & & 25 & $100 \%$ \\
\hline
\end{tabular}

Berdasarkan hasil rangkuman tabel-tabel di atas yang menyajikan hasil analisis persentase tiap aspek penilaian baik dari penilaian validasi ahli maupun penilain observasi. Hasil dari jumlah skor persentase aspek penilaian dari ahli materi mendapatkan persentase sebesar 80,30\% dengan kesimpulan kriteria kelayakan "sangat layak", hasil jumlah skor aspek penilaian dari ahli media mendapatkan persentase sebesar 80,30\% dengan kesimpulan kriteria kelayakan berada pada kriteria "sangat layak", hasil jumlah skor aspek penilaian dari ahli bahasa mendapat presentase sebesar $81,25 \%$ dengan kesimpulan kriteria kelayakan berada pada kriteria "sangat layak". Hasil dari keefektivitasan penggunaan modul yang ditinjau dari kemampuan kognitif siswa terlihat bahwa terdapat $76 \%$ siswa berada pada kriteria "tinggi" dan terdapat 24\% siswa berada pada kriteria "sedang". Hal ini sesuai dengan pendapat Wicaksono (dalam Suryani, 2014) yang menyatakan bahwa "keefektivitasan modul dilihat dari tingkat keberhasilan yang dicapai siswa dengan menggunakan modul. Kriteria keefektivitasan penggunaan modul apabila sekurang-kurangnya $75 \%$ dari jumlah siswa memperoleh kriteria tinggi". Dari hasil tersebut maka dapat disimpulkan bahwa produk 
Aria Tanti. W. S., Dedy. H. A.- Pengembangan Modul Berbasis ...

hasil pengembangan sudah sangat layak sehingga peneliti memutuskan untuk tidak melakukan revisi produk. Modul fisika berbasis POE produk hasil pengembangan ini sudah layak digunakan dalam pembelajaran di kelas.

Setelah produk awal dirancang dan dibuat, selanjutnya pada tahap ini kegiatan yang dilakukan validasi terhadap rancangan awal produk modul yang telah dibuat. Proses validasi dilakukan oleh enam ahli yaitu dua ahli materi, dua ahli media dan dua ahli bahasa. Ahli yang terpilih adalah tiga dosen dan tiga guru SMA yang sesuai dengan bidangnya. Berdasarkan hasil validasi ahli yang menggunakan lembar validasi oleh beberapa ahli dan lembar observasi uji coba pada siswa yang ditinjau dari kemampuan kognitif siswa maka data dianalisis kemudian dikorelasikan dengan tafsiran kriteria kelayakan modul.

\section{Analisis Data Validasi Ahli}

- Berdasarkan penilaian yang terbagi dalam tujuh aspek pada tabel 1, secara aspek keseluruhan modul fisika mendapat persentase kelayakan sebesar $80,20 \%$, nilai persentase tersebut berada pada kriteria "sangat layak" sehingga dapat dikatakan bahwa modul fisika berbasis POE yang dikembangkan sudah lengkap. Modul fisika berbasis POE ini dilengkapi dengan contoh-contoh soal, latihan soal, berpusat kepada siswa, materi yang mudah dimengerti oleh siswa dan dengan sajian informasi yang banyak sehingga sangat layak untuk digunakan dalam proses pembelajaran bagi siswa baik secara mandiri atau dengan arahan guru.

- Modul fisika berbasis berbasis POE (Predict, Observe, explain) yang dikembangkan telah divalidasi oleh ahli media. Data skor validasi yang diperoleh kemudian dianalisis. Berdasarkan penilaian pada tabel 2 yang terbagi dalam tujuh aspek di atas, secara aspek keseluruhan modul fisika mendapat persentase kelayakan sebesar 80,30\%, nilai persentase tersebut berada pada kriteria "sangat layak" sehingga dapat dikatakan bahwa modul fisika berbasis POE yang 
Aria Tanti. W. S., Dedy. H. A.- Pengembangan Modul Berbasis ...

dikembangkan dapat memenuhi tata letak kulit modul yang menarik sehingga siswa ingin mempelajarinya. Dalam modul juga terdapat gambar-gambar yang berwarna, hal tersebut membuat siswa ingin mengetahui dan mempelajari modul yang dikembangkan sehingga sangat layak untuk digunakan dalam proses pembelajaran bagi siswa baik secara mandiri atau dengan arahan guru.

- Berdasarkan skor validasi ahli bahasa yang diberikan terhadap modul fisika berasis POE (Predict, Observe, explain), maka data tersebut dianalisis. Berdasarkan tabel 3 penilaian yang terbagi dalam tiga aspek di atas, secara aspek keseluruhan modul fisika mendapat persentase kelayakan sebesar $81,25 \%$, nilai persentase tersebut berada pada kriteria "sangat layak" sehingga dapat dikatakan bahwa modul fisika berbasis POE yang dikembangkan siswa dapat memahami pesan yang terkandung dalam modul serta siswa dapat termotivasi setelah mempelajari modul yang dikembangkan sehingga sangat layak untuk digunakan dalam proses pembelajaran bagi siswa baik secara mandiri atau dengan arahan guru.

Berdasarkan hasil pengujian dari beberapa ahli terhadap materi, media dan bahasa diperoleh ratarata persentase seluruh ahli mencapai $80,80 \%$ atau terletak pada kriteria "sangat layak". Hal ini berarti modul berbasis POE dalam ahli materi, ahli media dan ahli bahasa pada materi usaha dan energi telah dinyatakan sangat layak.

\section{Analisis Data Keefektivan Penggunaan Modul}

Modul fisika berbasis POE (Predict, Observe, explain) telah melalui tahap uji validasi ahli. Hasil dari uji validasi di uji cobakan ke siswa guna melihat keefektivan penggunaan modul. Keefektivan penggunaan modul tersebut ditinjau dari kemampuan kognitif siswa yang terbagi menjadi empat aspek yaitu pengetahuan, pemahaman, penerapan, dan analisis. 
Aria Tanti. W. S., Dedy. H. A.- Pengembangan Modul Berbasis ...

\begin{abstract}
Berdasarkan tabel 4 tentang
hasil observasi keefektivan dari

penggunaan modul berbasis POE

yang ditinjau dari kemampuan

kognitif skor dari setiap aspek

penilaian tersebut dirata-rata,

didapatkan skor aspek keseluruhan

sebesar 13. Berdasarkan skor

observasi dari kemampuan kognitif

dapat dinyatakan bahwa modul fisika

berbasis POE yang dikembangkan

berada pada kriteria "tinggi". Hal ini

sesuai dengan pendapat Warsono dan

Hariyanto (2012: 93) model POE

adalah teknik pembelajaran yang

banyak dikembangkan dalam

pendidikan sains. Teknik ini dilandasi

oleh teori pembelajaran
\end{abstract}

konstruktivisme yang beranggapan

bahwa melalui kegiatan melakukan

prediksi, observasi dan menerangkan

sesuatu hasil pengamatan, maka

struktur kognitifnya akan terbentuk

dengan baik. Anggapan yang lain adalah bahwa pemahaman siswa saat ini dapat ditingkatkan melalui interaksinya dengan rekan sebayanya dalam kelas. Hal ini menunjukan bahwa modul fisika berbasis POE dapat digunakan dalam pelajaran di kelas maupun digunkan belajar secara mandiri oleh siswa.

\section{PENUTUP}

\section{Kesimpulan}

Produk hasil pengembangan yang berupa modul fisika POE (Predict, Observe, explain) untuk kelas XI SMA/MA yang berisi materi usaha dan energi. Selanjutnya dilakukan pengujian yakni uji ahli dan uji keefektivitasan penggunaan modul. Hal ini dilakukan untuk mengetahui bagaimana tingkat kelayakan dari ahli materi, ahli media, ahli bahasa dan keefektivitasan penggunaan modul ditinjau dari kemampuan kognitif siswa. Berdasarkan pengujian yang telah dilakukan produk hasil pengembangan mendapatkan persentase kelayakan dari ahli materi sebesar $80,68 \%$, persentase kelayakan dari ahli media sebesar 80,30\%, persentase kelayakan bahasa sebesar $81,25 \%$. Keefektivitasan penggunaan modul ditinjau dari kemampuan kognitif siswa, tahap ini merupakan tahap penggunaan modul berbasis POE yang telah divalidasi oleh beberapa ahli. Rata- rata skor yang diperoleh kelas XI IPA 3 adalah 13 
Aria Tanti. W. S., Dedy. H. A.- Pengembangan Modul Berbasis ...

dengan kriteria tinggi. Berdasarkan

persentase yang didapatkan dari uji ahli dan uji keefektivitasan tersebut maka dapat disimpulkan bahwa modul fisika berbasis POE yang dikembangkan terletak pada kriteria kelayakan "sangat layak", sehingga modul yang telah dikembangkan dapat digunakan dalam kegiatan pembelajaran di kelas. Modul fisika berbasis POE dikatakan sangat layak karena telah melalui tahapan uji ahli dan uji keefektivitasan.

\section{Saran}

\section{Saran Keperluan Pemanfaatan}

Produk

Dalam penggunaan produk modul fisika berbasis POE (Predict, Observe, explain) perlu adanya persiapan yang matang dari guru. Guru harus terlebih dahulu mengarahkan siswa untuk memahami pengetahuan prasyarat yang wajib dipahami oleh siswa sebelum masuk ke metode POE (Predict, Observe, explain). Dengan alasan, siswa belum mengenal metode tersebut perlu adaptasi dalam melakukan kegiatan pembelajaran.

\section{Saran Diseminasi/Penyebaran} Produk

Modul fisika berbasis POE (Predict, Observe, explain) diharapkan dapat digunakan dalam pembelajaran pada kelas sesungguhnya yaitu dengan jumlah siswa yang lebih banyak.

\section{Saran Pengembangan Lanjutan \\ Produk}

Modul fisika berbasis POE (Predict, Observe, explain) ini hanya dikembangkan pada materi usaha dan energi, sehingga diharapkan ada pengembangan pada materi pelajaran fisika yang lain. Modul fisika berbasis POE ini hanya ditinjau dari kemampuan kognitif siswa diharapkan ditambahkan kolom kritik dan saran tentang penggunaan modul oleh siswa di dalam modul. Perlu melakukan penelitian tindakan sejenis dengan subjek penelitian yang lebih banyak dan rentang waktu yang lebih panjang dengan karakteristik siswa yang berbeda/tertentu untuk memperoleh hasil yang lebih baik.

\section{DAFTAR PUSTAKA}

Asyhar, Rayandra. 2011. Kreatif Mengembangkan Media 
Aria Tanti. W. S., Dedy. H. A.- Pengembangan Modul Berbasis ...

Pembelajaran. Jakarta: Gaung Persada (GP) Press.

Mulyatiningsih, Endang. 2014.

Metode Penelitian Terapan Bidang

Pendidikan. Bandung: Alfabeta.

Restami M. P, K. Suma, dan M.

Pujani. 2013. Pengaruh Model

Pembelajaran POE (Predict-

Observeexplaint) Terhadap

Pemahaman Konsep Fisika Dan

Sikap Ilmiah Ditinjau Dari Gaya

Belajar Siswa. e-Journal Program

Pascasarjana Universitas

Pendidikan Ganesha, volume 3.

Suryani, Tatang, dan Rachman. 2014.

Pengembangan Modul Kimia

Reaksi Reduksi Oksidasi Kelas X

SMA. J.Pen.Pend.Kim,2014,1 (1), 18-28.

Warsono, dan Hariyanto. 2012.

Pembelajaran Aktif. Bandung:

PT Remaja Rosdakarya.

Widyaningrum, Ratna, Sarwanto, dan

Puguh, Karyanto. 2013.

Pengembangan Modul Berorientasi

POE(Predict, Observe, Explain)

Berwawasan Lingkungan Pada

materi Pencemaran Untuk

Meningkatkan Hasil Belajar

Siswa. Jurnal BIOEDUKASI.

ISSN: 1693-2654. Volume 6,

Nomor 1 Halaman 100-117,

Februari 2013. 